\title{
Erosion problem in tool steel using cold box core-making process
}

\author{
*Eduardo Rodríguez ${ }^{1}$, Alberto Pérez², Rafael David Mercado-Solis ${ }^{2}$, Velasco-Téllez Abraham ${ }^{3}$, Omar $^{2}$ \\ Jiménez ${ }^{1}$, Martín Flores ${ }^{1}$, Marco Aurelio González ${ }^{1}$, Jesús Ibarra ${ }^{4}$ \\ 1. Universidad de Guadalajara, Departamento de Ingeniería de Proyectos/CUCEI, CONACyT, México; \\ 2. Facultad de Ingeniería Mecánica y Eléctrica, UANL, México; \\ 3. Nemak México, S.A., García, México; \\ 4. Instituto Tecnológico José Mario Molina Pasquel y Henríquez, Unidad Zapopan, México.
}

\begin{abstract}
This paper presents the erosion results of the AISI H13 steel impinged by resin-bonded silica sand, using a testing rig that closely simulates the real blowing conditions during industrial core-making. Steel specimens were heat treated to obtain hardness of 294, 445 and $595 \mathrm{HV}_{200}(29,45$ and $55 \mathrm{HRC})$. Erosion tests were carried out at impingement angles from $20^{\circ}$ to $90^{\circ}$ and air drag pressures of 1.38, 2.07 and 2.76 bar (20, 30 and $40 \mathrm{psi}$ ). The main results are summarized as follows: (i) The harder material, the lower erosion; (ii) the maximum erosion rate is at $30^{\circ}$; (iii) Little difference in erosion rate at impact angle of $60^{\circ}$ and $90^{\circ}$ for a constant pressure tested regardless of the hardness level; (iv) As the pressure increases, so does the erosion rate, being more sensitive for low impact angles. Finally, a differential form of the general erosion equation is applied on a practical core-making case to evaluate the erosion rate of the $\mathrm{H} 13$ steel at $30^{\circ}$ and $90^{\circ}$ impingement angles.
\end{abstract}

Key words: erosion; cold box; core-making; H13 tool steel; resin coated silica sand
CLC numbers: TG142.45
Document code: A
Article ID: 1672-6421(2019)03-204-07

$\mathrm{T}$ he cold box process using silica sand coated with resin binder is common in the casting industry for fabricating a broad range of sand cores ${ }^{[1-3]}$. The core, a mould part, is used to form internal holes and cavities in cast article $\mathrm{e}^{[4]}$, which is molded when the coated sand in the magazine is injected into the cavities of the core box through the nozzles by high-pressure flow of dry air (Fig. 1). After the sand fills into the cavities, a vaporized catalyzer amine ${ }^{[5,6]}$ is added to produce a solid sand core at room temperature. The AISI H13 tool steel is widely used to build up such core boxes. Particle erosion is the erosive wear caused by the impingement of solid particles ${ }^{[7]}$. Therefore, the coated sand impinging against the tool steel causes the erosion problem in many foundries.

The progressive loss of steel by erosion (Fig. 2) can result in dimensional variations which may overpass

\section{*Eduardo Rodríguez}

Male, born in 1966, Ph.D., Titular Researcher. Member of the National Research System. His research focuses on physical metallurgy (wear of materials, welding metallurgy, heat treatment).

E-mail: eduardo.deanda@hotmail.com

Received: 2018-11-13; Accepted: 2019-01-26 tolerances. Since the erosive wear cannot be avoided, it is significant to investigate the influence of many variables on the erosive wear to mitigate the erosive wear on the core boxes. Those different variables are classified by Finnie ${ }^{[8]}$ and others ${ }^{[9,10]}$ as follows:

(1) Flow conditions: Impingement angle $\mathrm{e}^{[11,12]}$, speed $^{[13-16]}$ and rotation ${ }^{[17,18]}$ of the particle, concentration of particles within the fluid, nature of the fluid and its temperature.

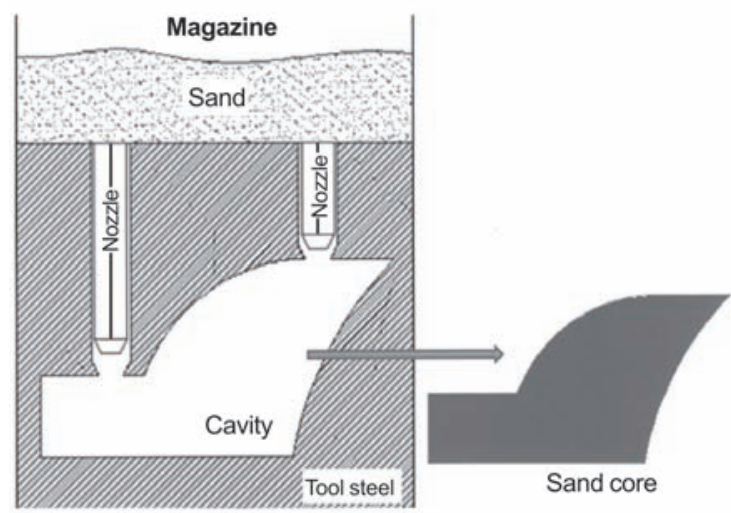

Fig. 1: Schematic representation of core making process 


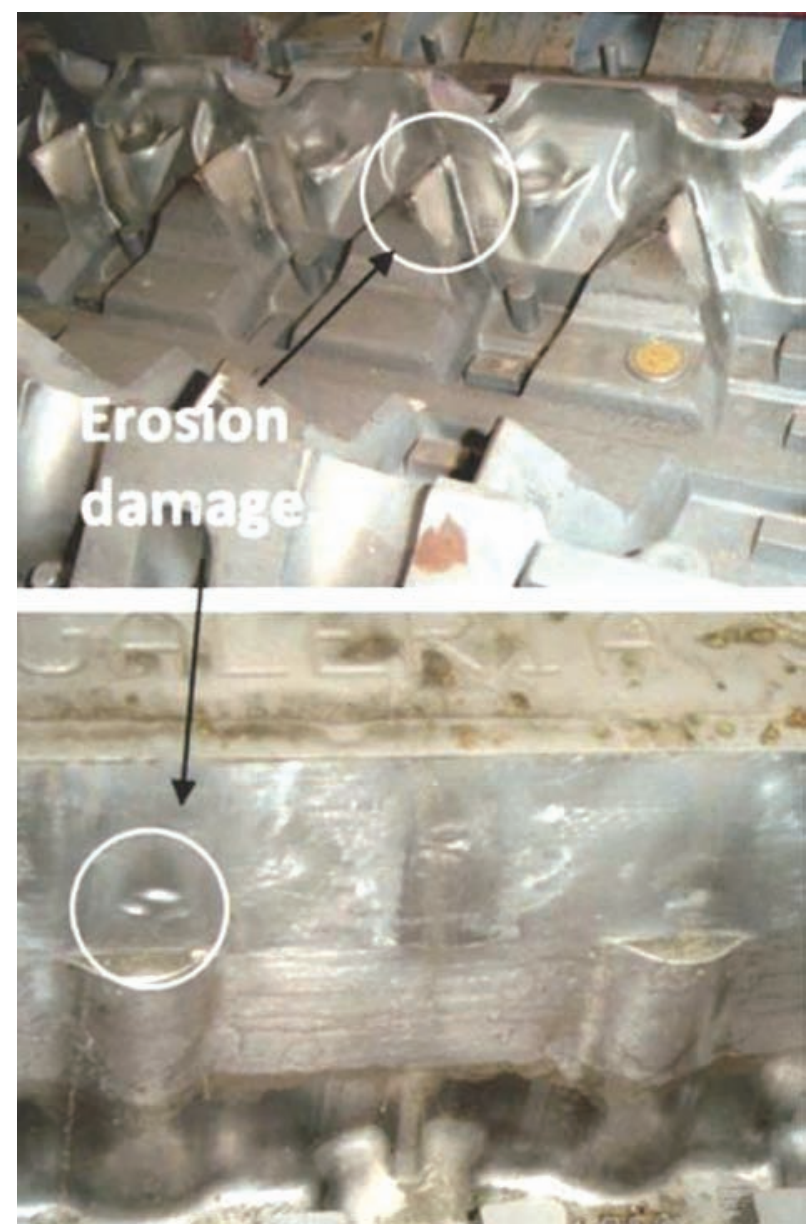

Fig. 2: Erosion damage in AISI H13 steel core boxes

(2) Particle properties ${ }^{[19,20]}: \mathrm{Size}^{[21,25]}$, shape $\mathrm{e}^{[26-31]}$, hardness ${ }^{[32]}$, brittleness (resistance to fragmentation), and density.

(3) Surface properties: speed of deformation, temperature, toughness, hardness, stress level and residual stress, microstructure, topography, and ductility.

Some researchers ${ }^{[33-36]}$ have studied the erosion of core-box materials. In their experimental procedures, the erosive media was not modified with the resins, and the erosion happens in the core-making process. The resins can modify the tribological system with obvious differences on the erosion resistance of the AISI H13 steel in comparison with the system where resins are not used.

The aim of this work was to study the erosive wear of the AISI H13 tool steel by resin coated silica sand, which is a serious problem in the foundry industry around the world. No results are reported using the pressure, impact angle and target hardness as the main variables in a system that simulates the cold box core making process at room temperature, such as resin coated silica sand with $0.8 \mathrm{wt} . \%$ of resins, grain fineness number (AFS-GFN) of 47 , dry air $\left(-40^{\circ} \mathrm{C}\right.$ dew point), $12.7 \mathrm{~mm}$ nozzles. Additionally, the general erosion equation is as follow:

$$
\text { Erosion }=m_{\text {material }} / m_{\text {erodent }}
$$

where $m_{\text {material }}$ is the mass of eroded material, $m_{\text {erodent }}$ is the rodent mass. The equation (1) is modified into a differential equation form to be applied to a practical case where the drag pressure and the erodent flow change with time.

\section{Experimental}

\subsection{Materials}

The chemical composition of the steel was determined by arc emission spectrometry and is given in Table 1. The surface roughness $R q$ of the AISI H13 tool steel was below $1 \mu \mathrm{m}$ according to the ASTM G76 standard ${ }^{[37]}$. Each erosion test used an average of $34 \mathrm{~kg}$ of binder-coated silica sand with 0.8 wt. $\%$ of resin.

Table 1: Chemical composition of AISI H13 steel (wt.\%)

\begin{tabular}{ccccccc} 
C & Mn & Si & Cr & Mo & V & Fe \\
\hline 0.396 & 0.48 & 1.02 & 5.31 & 1.23 & 0.94 & Bal.
\end{tabular}

\subsection{Experimental variables}

Table 2 shows the experimental variables considered in this work. Several impingement angles $\left(20^{\circ}, 30^{\circ}, 60^{\circ}\right.$ and $\left.90^{\circ}\right)$ were selected considering the variety of impact angles that can be found in a core box. Besides, a ductile material shows its maximum erosion rate at low-angle impact, whereas a brittle one does it at high-angle impact, so it is important to know the ductile or brittle behavior of the H13 steel. Because excellent harden ability of the H13 tool steel can be obtained by quenching and tempering, hardness values of soft (294 $\mathrm{HV})$, medium (445 HV) and hard (595 HV) were taken into account to study the heat treatment for the steel. Air drag pressures used in the present work are those measured typically at the core boxes during blowing in industrial coremaking processes. There are pressure differences between the line accumulator and the core (around $65-70 \mathrm{psi})^{[2,39]}$, whereas pressure differences from 0.0 to 40 psi between the magazine and the core are reported for intervals from 0.0 to $0.8 \mathrm{~s}^{[39]}$ of the filling step on the core-making process.

\section{Table 2: Experimental variables}

\begin{tabular}{|ccc|}
\hline Angles & Hardness $\left(\mathbf{H V}_{\mathbf{2 0 0}}\right)$ & Pressure (bar) \\
\hline $20^{\circ}, 30^{\circ}, 60^{\circ}$, and $90^{\circ}$ & 294,445 and 595 & $1.38,2.07$ and 2.76 \\
(respect to the surface) & $(29,45$ and 55 HRC) & $(20,30$ and 40 psi)
\end{tabular}

\subsection{Testing conditions}

Figure 3 shows the testing rig used in this work. The magazine (sand chamber) of the rig was loaded with the binder-coated silica sand AFS-GFN 47. The sand flow derived by the blowing pressure through the exit nozzle impinges the sample at a desired angle inside the chamber. The impingement time was recorded and the silica sand was collected to obtain the sand flow at the different blowing pressures. The diameter of the 
exit nozzle was $12.7 \mathrm{~mm}$. The air drag was dry air with a dew point of $-45^{\circ} \mathrm{C}$. Samples were ultrasonically cleaned in an acetone bath for 5 minutes before and after each erosion test. The weight loss was measured by an analytical balance with a resolution of $0.1 \mathrm{mg}$. Erosion rate was calculated dividing the total weight loss from the sample $(\mathrm{mg})$ by the total amount of blown sand $(\mathrm{kg})$. Thus, the erosion per mass unit of erodent

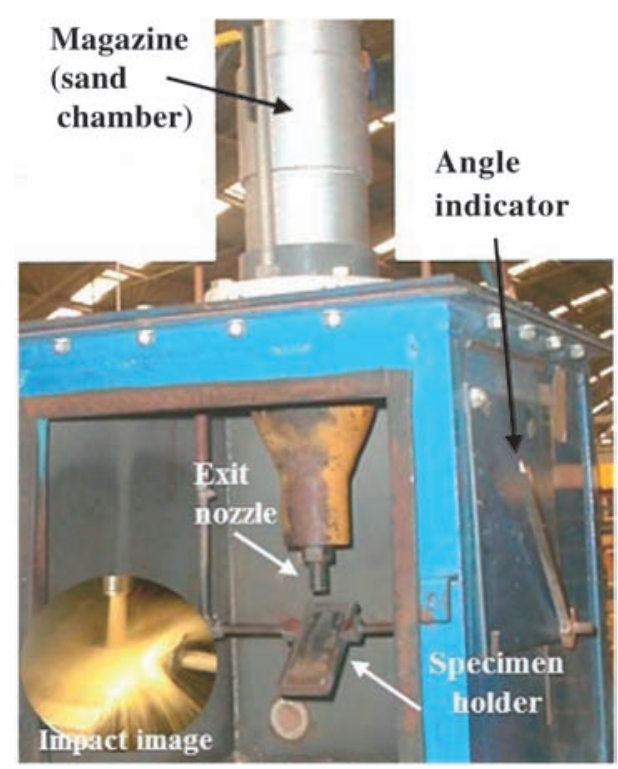

Fig. 3: Components of erosive rig employed
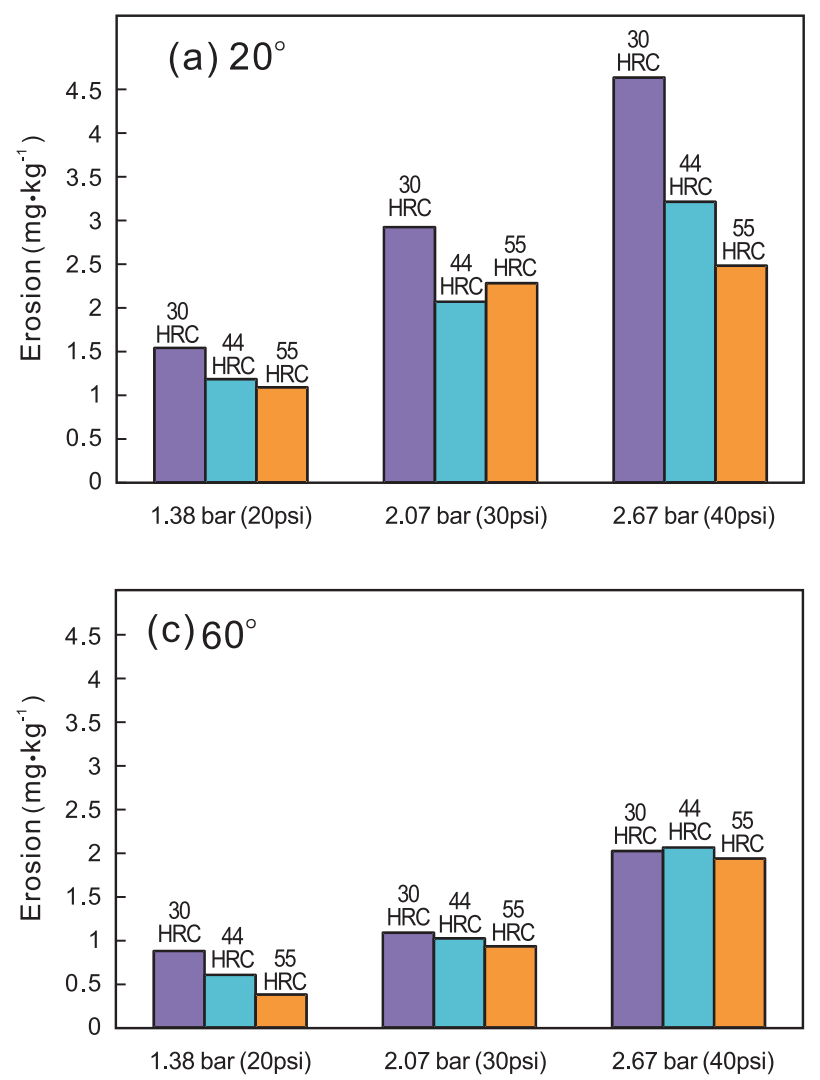

was taken $\left(\mathrm{mg} \cdot \mathrm{kg}^{-1}\right)$. SEM observations were performed to obtain the morphology deformation of the erosion scars.

\section{Results and discussion}

\subsection{Erosion plots}

\subsubsection{Effect of hardness}

Figure 4 shows the average erosion rate at different impact angles $\left(20^{\circ}, 30^{\circ}, 60^{\circ}\right.$ and $\left.90^{\circ}\right)$ with different $\mathrm{H} 13$ steel hardness values of $294 \mathrm{HV}$ (soft, $30 \mathrm{HRC}$ ), $445 \mathrm{HV}$ (medium, $44 \mathrm{HRC}$ ) and $595 \mathrm{HV}$ (hard, 55 HRC). For a fixed blow pressure and impact angle, the hardest material (595 HV) presents a lower erosion rate compared with the softer material (294 HV) does. This effect is more sensitive for low-angle erosion (Fig. 4 a and b) where the difference in erosion between the hardest and the softest steel is greater and increases with increasing the blow pressure. In the case of high-angle impact (Fig. $4 \mathrm{c}$ and d) the difference in erosion between the soft and hardened steels is less; even at the high pressure, the differences in the erosion rates are almost negligible.

\subsubsection{Effect of impact angle}

The maximum erosion rate was observed at low-angle impact, indicating the ductile behavior ${ }^{[8,36,38]}$ of the H13 steel, even in the hardened condition of $595 \mathrm{HV}$. It is even clear that the excellent erosion resistance performance was displayed by the
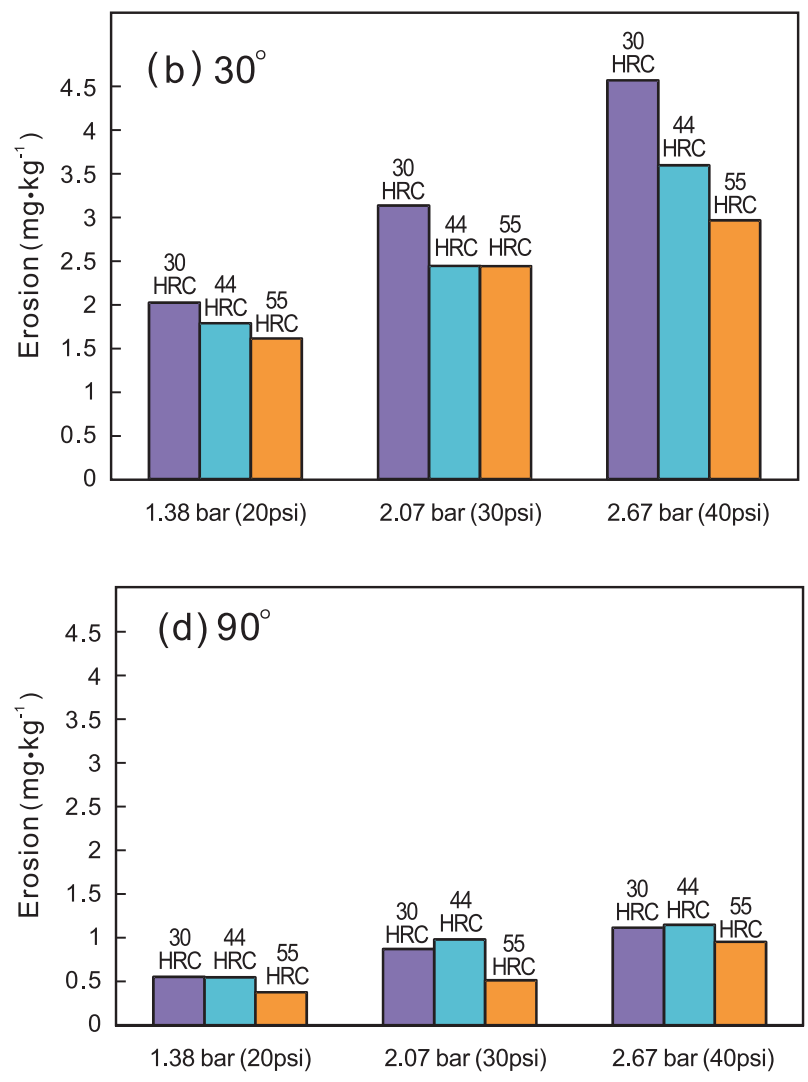

Fig. 4: Erosion rates $\left(\mathrm{mg} \cdot \mathrm{kg}^{-1}\right)$ at pressures of $1.38,2.07$ and 2.67 bar: (a) $20^{\circ}$ impact, (b) $30^{\circ}$ impact, (c) $60^{\circ}$ impact, and (d) $90^{\circ}$ impact. 
hardest steel in low-angle impact (Fig. $4 \mathrm{a}$ and b). The lowest erosion rate is shown at the impact angle of $90^{\circ}$ (Fig. $4 \mathrm{~d}$ ), and erosion values tend to converge at high-angle impingement.

\subsubsection{Effect of pressure}

Erosion rate increases with the pressure increasing. However, in the case of $90^{\circ}$ impact angle, the erosion rate is less sensitive to the increase of the pressure (Fig. 4 d). In contrast, for low-angle impact (Fig. $4 \mathrm{a}$ and b), the increase of pressure results in a great increase of mass loss.

\subsection{Morphologies of eroded surfaces}

Figure 5 shows erosion surface of $\mathrm{H} 13$ steel at $30^{\circ}$ impact angle. Many grooves are formed due to the cutting effect of the multiple impacts. For the low impact angle, there is a tangential component and a perpendicular component of the impact force. The perpendicular component can penetrate deeper in the soft material, the tangentials component can take away the material from the surface and/or leave an amount of plastic deformation in front of and on both sides of the impact mark. This plastic deformation is susceptible to be detached by successive impacts. As a result, deeper grooves and more plastic deformation are created on the softer material than on the harder one, as can be observed by comparing Figs. 5(a) and 5(b), resulting in a greater mass loss of the H13 steel.

In the case of $90^{\circ}$ impact angle, only the normal component exists and the crater is the main erosion mechanism. In Fig. 6, it can be observed that the crater is formed due to multiple impact particles on the material surface. For the soft steel, these craters are larger in size with a great amount of plastic
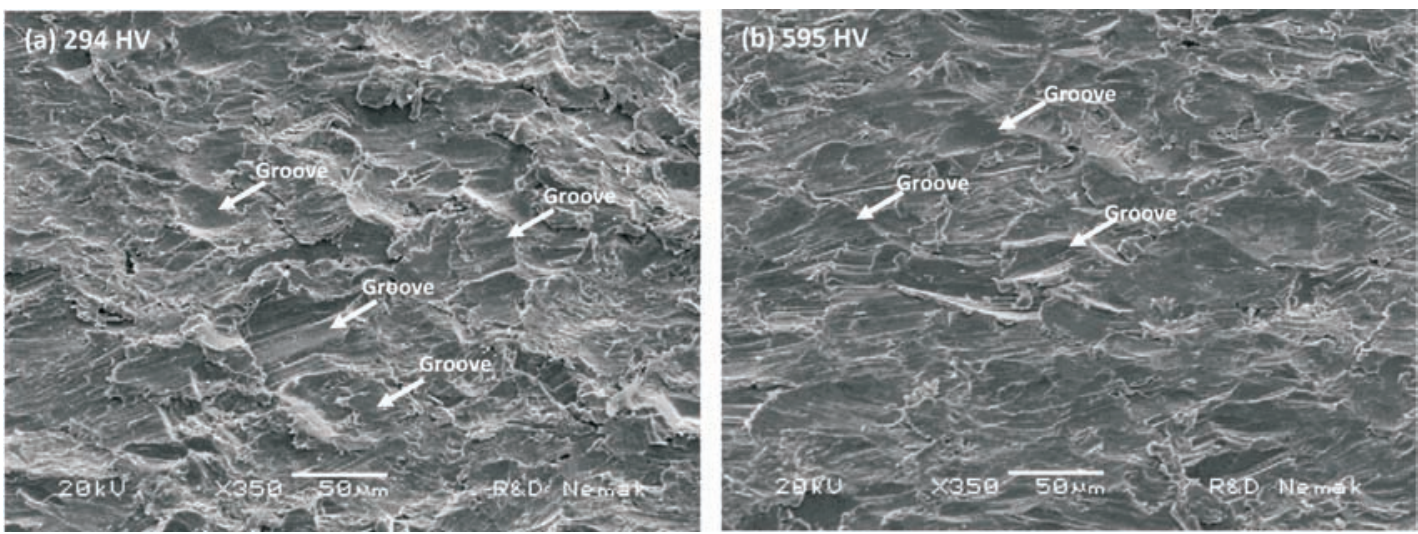

Fig. 5: Erosion surface of $\mathrm{H} 13$ steel at $30^{\circ}$ impact angle: (a) $294 \mathrm{HV}$ (30 HRC); (b) 595 HV (55 HRC)

deformation around the impact point (Fig. 6a) compared with that on the hardest steel eroded surface (Fig. 6b). Due to the better ductility of the softer steel, these craters and plastic deformation do not necessarily imply the detachment of the materials. So, it makes sense that for both materials, the mass loss happened at the same rate despite the great difference in surface appearance. For both images, it can be observed that the grooves, characteristic of the low angle impact, are total absence, because the low angle impact leads to the greater material detachment, with a greater influence on the softer steel.

\subsection{Comparison with no resin-coated sand system}

The main differences in the erosion trends between the no resin-coated sand system ${ }^{[36]}$ and resin-coated sand system can be pointed out as follows:

(1) In the system with no resin-coated sand, $1 \mathrm{~kg}$ of erosive material was enough to accurately measure the weight loss using the analytical balance, whereas the system using resincoated silica, around $34 \mathrm{~kg}$ and higher blowing pressures were needed to achieve trustable measurements.
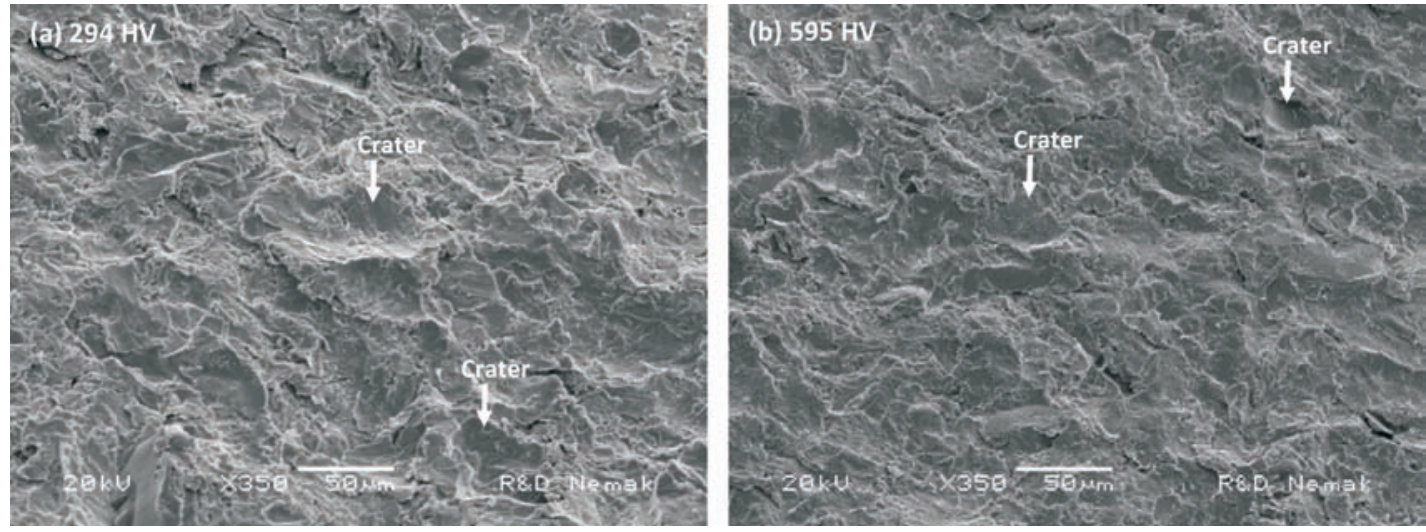

Fig. 6: Erosion surface of $\mathrm{H} 13$ steel at $90^{\circ}$ impact angle: (a) 294 HV (30 HRC); (b) 595 HV (55 HRC) 
(2) In the system with no resin-coated sand, the concurrent point for similar erosion rates was observed at an impingement angle of $30^{\circ}$; while in the system using resin-coated resins, such concurrent point occured at high-angle impingement. For these conditions, the hardness level of the steel is not critical.

(3) In the system with no resin-coated sand, the steel with a hardness of $595 \mathrm{HV}$ presented a maximum erosion rate at $60^{\circ}$, showing a brittle behavior (maximum erosion rate at high-angle impact), while in the present work, the behavior was always ductile with the maximum erosion rate at $30^{\circ}$ impact angle.

These differences are mainly due to two conditions: Firstly, the binder-coated silica seems to decrease the direct impact of the particles on the sample surface. The silica particles agglomerates due to the nature of resin. The impact speed decreases and energy dissipates during the agglomerate fragmentation due to the impact with the steel surface. In addition, the resin acts as a lubricant contributing to the slip of the particles affecting the cutting effect and also reducing the normal force component of the impact. This explains why an oblique impact over a highly hardened material shows less erosion.

Secondly, in the system with no resins, an average impact speed of 76 and $99 \mathrm{~m} \cdot \mathrm{s}^{-1}$ were reported for pressures of 0.69 and 1.38 bar respectively, ${ }^{[36]}$ while in the system using resins, a much lower impact speed of $9.5 \mathrm{~m} \cdot \mathrm{s}^{-1}$ was measured. Laura P. $\mathrm{McCabe}^{[11]}$ showed that the AISI 1050 carbon steel presented a higher erosion rate for a martensitic microstructure (water quenched) than a normalized pearlitic microstructure at a speed of $68 \mathrm{~m} \cdot \mathrm{s}^{-1}$ using $\mathrm{Al}_{2} \mathrm{O}_{3}$ (240 mesh) impingement particles. However, at a lower impact speed such as $28 \mathrm{~m} \cdot \mathrm{s}^{-1}$, an opposite trend was observed. That is to say, erosion resistance depends on the impact speed of the tribological system.

\subsection{Predictive equation to calculate mass loss of core box}

\subsubsection{Differential form of erosion equation}

In the process of making a sand core, a difference in pressure between the magazine and the mould cavity drives the sand to flow from the magazine through the nozzles to fill the mould cavity (Fig.1). Such difference in pressure changes with time. Figure 7 shows experimental values for a specific core box ${ }^{[39]}$. This variation in turn generates a variable sand flow, thus, both pressure changing and sand flow changing directly influence the material erosion rate. Due to the above mentioned factors, the traditional equation to calculate the erosion rate, equation (1), should be changed to the differential equation (2).

$$
E=\frac{d m_{\text {material }}}{d m_{\text {erodent }}}
$$

where $d m_{\text {material }}$ is the differential of the eroded material mass, $d m_{\text {erodent }}$ is the differential of the erodent mass.

The eroded mass material [equation (3)] can be calculated from equation(2)

$$
m_{\text {maxtrial }}=\int \text { Erosion } d m_{\text {erodent }}
$$

Taking into account that:

$$
\text { Flow }_{\text {erodent }}=\frac{d m_{\text {erodert }}}{d t}
$$

where $d t$ is a differential of time, equation(5) can be obtained from equation(3):

$$
m_{\text {matcrial }}=\int \text { Erosion }^{*} \text { Flow }_{\text {erodent }} d t
$$

To solve equation (5), it is necessary to have the Erosion and the Flow ${ }_{\text {erodent }}$ as a function of time $(t)$. Considering the erosion case of $30^{\circ}$ impact on a $30 \mathrm{HRC} \mathrm{H13}$ steel, Figs. 7 and 8 can be used since they correlate Erosion as a function of pressure $(P)$, and $P$ as a function of $t$, giving as a result Erosion as a function of $t$. In a similar way, to have Flow $_{\text {erodent }}$ as a function of $t$, Figs. 7 and 9 can be used because they correlate the Flow $_{\text {erodent }}$ as a function of $P$, and $P$ as a function of $t$. The final graph and its polynomial equation are shown in Fig. 10.

Substituting the equations showed in Figs. (8) and (10) into equation (5), $m_{\text {material }}$ can be obtained:

$$
\begin{aligned}
m_{\text {material }}= & 10^{-6} \int\left(0.156 P^{2}+1.215 P+0.006\right)\left(-35.43 t^{2}+\right. \\
& 39.82 t+0.1197) d t
\end{aligned}
$$

(The factor $10^{-6}$ is due to the erosion units: $\mathrm{mg} \cdot \mathrm{kg}^{-1}$ )

Considering a sand-metal impingement interval time from 0 to $0.25 \mathrm{~s}$, the pressure-time polynomial equation can be obtained from Fig. 7:

$$
\begin{aligned}
P= & -11387 t^{5}+5328 t^{4}-600 t^{3}+11.39 t^{2}+ \\
& 0.61 t-0.004
\end{aligned}
$$

The pressure in equation (6) is substituted by equation (7), and the mass loss for a single blow that fills one cavity can be obtained as follows:

$$
m_{\text {material }}=6.4498 \times 10^{-7} \mathrm{~g} \cdot\left(\mathrm{blow} \cdot \mathrm{mm}^{2}\right)^{-1}
$$

In a similar way for the $595 \mathrm{HV}$ hardened steel, at $30^{\circ}$ impact angle, the mass loss for a single blow that fills one

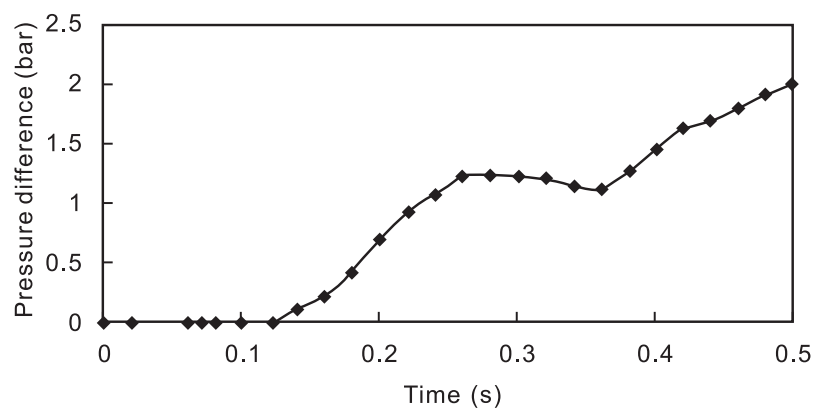

Fig. 7: Pressure difference between magazine and cavity versus time

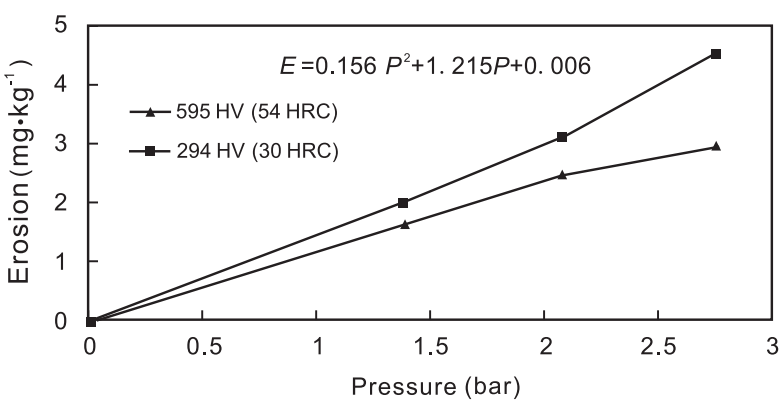

Fig. 8: Erosion rate values versus pressure at $30^{\circ}$ impact angle (values taken from Fig. 4) 


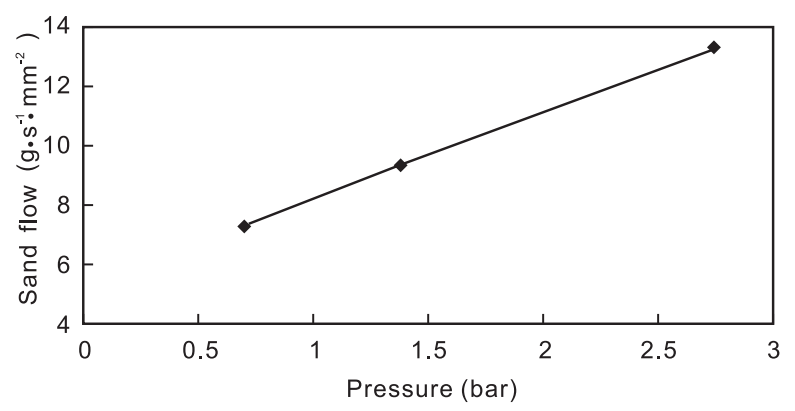

Fig. 9: Measured erodent flow shown in Fig. 3, as function of pressure

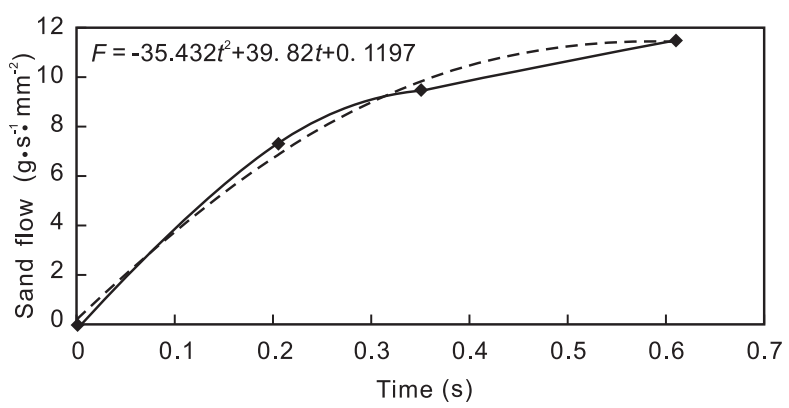

Fig. 10: Erodent flow as function of time. Polynomial equation of Flow erodent $_{\text {is included }}$

cavity can be obtained as follows:

$$
m_{\text {material }}=5.9121 \times 10^{-7} \mathrm{~g} \cdot\left(\mathrm{blow} \cdot \mathrm{mm}^{2}\right)^{-1}
$$

Similarly, mass loss was obtained for the sand-metal impingement interval time from 0 to $0.36 \mathrm{~s}$. Table 3 shows the calculated results for different impact angles, hardness and sand-metal impact time. Table 3 also shows that the erosion resistence can be improved to 23 times using the hardest steel (595 HV), an impact angle of $90^{\circ}$ and a relatively short sandmetal impact time $(0-0.25 \mathrm{~s})$. This can be easily observed in the core box and nozzles pattern shown in Fig. 1. The left nozzle will generate less erosion than the right nozzle does because of the normal impact angle and the decreasing sandmetal impact time. The sand-metal impact time is reduced because the initial sand-to-metal impact is substitued by a sand-to-sand impact due to the filling effect of the cavity that covers the initially exposed metal.

\section{Conclusions}

This paper presents the erosion behavior of the AISI H13 tool steel as a function of the hardness, impact angle and pressure using resin-bonded silica sand on a system that closely simulates the core-making process in the foundry industry. The results from this work indicate that:

(1) The hardest H13 steel (595 HV) shows the best erosion resistance for a fixed blow pressure and impact angle. This advantage is more sensitive for low-angle impact erosion than for the high-angle impact case where at high drag pressure, the differences in erosion rate are almost negligible.
Table 3: Calculated erosion results under pointed blowing conditions, using resin-coated silica sand

\begin{tabular}{|c|c|c|c|c|}
\hline Angle & $\begin{array}{l}\text { Impact time } \\
\text { (sec) }\end{array}$ & $\begin{array}{l}\text { Hardness } \\
\text { HV (HRC) }\end{array}$ & $\begin{array}{l}\text { Erosion } \\
{\left[10^{-6} \mathrm{~g} *\left(\text { blow } \mathrm{mm}^{2}\right)^{-1}\right]}\end{array}$ & $\begin{array}{l}\text { Improve } \\
\text { factor }\end{array}$ \\
\hline \multirow{4}{*}{$30^{\circ}$} & $0-0.25$ & $294(30)$ & 0.64498 & 3.5 \\
\hline & $0-0.25$ & $595(54)$ & 0.59121 & 3.8 \\
\hline & $0-0.36$ & $294(30)$ & 2.2726 & 1.0 \\
\hline & $0-0.36$ & 595 (54) & 2.0115 & 1.1 \\
\hline \multirow{4}{*}{$90^{\circ}$} & $0-0.25$ & $294(30)$ & 0.20108 & 11.3 \\
\hline & $0-0.25$ & $595(54)$ & 0.098719 & 23.0 \\
\hline & $0-0.36$ & $294(30)$ & 0.68659 & 3.3 \\
\hline & $0-0.36$ & 595 (54) & 0.35497 & 6.4 \\
\hline
\end{tabular}

(2) The maximum erosion rate happens at low-angle impact $\left(30^{\circ}\right)$ in most cases (ductile behavior). Low-angle impact was clearly the advantage of the harder H13 steel. For high-impact angles, in most of the cases the erosion rate remains almost constant despite the different hardness values.

(3) As the drag pressure increases, the erosion rate increases; for the $90^{\circ}$ impact angle, the erosion rate is less sensitive to the increase of the blow pressure. In contrast, at low angle, the increase of pressure results in a great increase of mass loss.

(4) For low-angle impact, there are grooves due to the cutting effect of multiple impacts, but for the softest steel, the grooves are deeper, demostrating a greater plastic deformation and greater mass loss. For the $90^{\circ}$ impact angle, on the softest steel there are larger craters and plastic deformation than those on the hardest steel, but with no greater detachment of the material, resulting in almost the same erosion rate despite the surface appearance.

(5) The experimental data and the differential equation for a variable erosion rate show that the most detrimental case concerning erosion of a core box is the use of the soft steel, low-angle impact, high drag pressure in a core box design that allows relatively long sand-steel impact time. The calculated improvements in erosion resistance were up to 23 times.

\section{References}

[1] Ni Changjiang, Lu Gaochun, Zhang Qingdong, et al. Influence of core box vents distribution on flow dynamics of core shooting process based on experiment and numerical simulation. China Foundry, 2016, 13: 22-29.

[2] Bakhtiyarov S, Overfelt R. CFD modeling and experimental study of resin-bonded sand/air two-phase flow in sand core making process. Powder Technol., 2003, 133: 68-78.

[3] Wan Peng, Li Luancai, Long Zhang et al. Research on testing 
method of resin sand high temperature compressive strength. China Foundry, 2016, 13: 335-341.

[4] Czerwinski F, Mir M, Kasprzak W. Application of cores and binders in metal casting. International Journal of Cast Metals Research, 2015, 28: 129-139.

[5] Technical bulletin, The Ashland Process, Foundry Products Division, Ashland Chemical, 1998

[6] González R. Efecto de la Temperatura Sobre las Propiedades Físicas de Moldes y Corazones Producidos por el proceso Fenol-Uretano en Caja Fría, Universidad Autónoma de Nuevo León, 2001. (In Spanish)

[7] Cheng T W, Chen L H, Lui T S. Particle erosion of die cast Al$14 \mathrm{Si}$ alloy and influence of friction stir process. International Journal of Cast Materials Research, 2012, 25(3): 155-159.

[8] lain Finnie. Some reflections on the past and future of erosion. Wear, 1995, 186-187: 1-10.

[9] Sundararajan G. The solid particle erosion of metallic materials: the rationalization of the influence of material variables. Wear, 1995, 186-187: 129-144.

[10] McCabe L, Sargent G, Conrad H. Effect of microstructure on the erosion of the Steel by solid particles, Wear, 1985, 105: 257-277.

[11] Nguyen Q B, Nguyen V B, HLim C Y, et al. Effect of impact angle and testing time on erosion of stainless steel at higher velocities. Wear, 2014, 321: 87-93.

[12] Das S, Mondal D P, and Sawla S. Solid particle erosion of A alloy and Al-alloy composites: effect of heat treatment and angle of impingement. Metallurgical and Materials Transactions A, 2004, 35A: 1369-1379.

[13] Akihiro Y, Kazuo M, Masanobu M. Critical impact velocity in the solid particles impact erosion of metallic materials. Wear, 1999 233-235: 468-475.

[14] Mohajerani A, Spelt J K. Erosive wear of borosilicate glass edges by unidirectional low velocity impact of steel balls. Wear, 2010, 269: 900-910.

[15] Mohajerani A, Spelt J K. Erosive wear of borosilicate glass by low velocity unidirectional impact of abrasive spheres. Wear, 2011, 270: 866-875

[16] Stevenson A N J, Hutchings I M. Scaling laws for particle velocity in the gas-blast erosion test. Wear, 1995, 181-183: $56-62$.

[17] Nguyen $\vee \mathrm{B}$, Nguyen $\mathrm{Q} B$, Lim C Y H, et al. Effect of airborne particle-particle interaction on materials erosion. Wear, 2015, 322-323: 17-31.

[18] Deng T, Bingley M S, Bradley M S A. The influence of particle rotation on the solid particle erosion rate of metals. Wear, 2004, 256: 1037-1049.

[19] Murugesh L, Scattergood R O. Effect of erodent properties on the erosion of alumina. Journal of Materials Science, 1991, 26: $5456-5466$

[20] Bousser E, Martinu L, Klemberg-Sapieha J E. Effect of erodent properties on the solid particle erosion mechanisms of brittle materials. J Mater Sci, 2013, 48: 5543-5558.

[21] Nguyen $\vee$ B, Nguyen Q B, Zhang $Y$ W, et al. Effect of particle size on erosion characteristics. Wear, 2016, 348-349: 126137.
[22] Padhy M K, Saini R P. Effect of size and concentration of silt particles on erosion of Pelton turbine buckets. Energy, 2009, 34: $1477-1483$.

[23] Nan Lin, Arabnejad H, Shirazi S A, et al. Experimental study of particle size, shape and particle flow rate on erosion of stainless steel. Powder Technology, 2018, 336: 70-79.

[24] Macchini R, Bradley M S A, Deng T. Influence of particle size, density, particle concentration on bend erosive wear in pneumatic conveyors. Wear, 2013, 303: 21-29.

[25] Venugopal Reddy A and Sundararajan G. The Influence of Grain Size on the Erosion Rate of Metals. Metallurgical Transactions A. 1987, 18A: 1043-1052.

[26 Laguna-Camacho J R, Hernández-Romero I. EscalanteMartínez J E, et al. Erosion Wear of AISI 420 Stainless Steel Caused by Walnut Shell Particles. Trans Indian Inst Met, 2015, 68(4): 633-647.

[27] Muhammad N, Henry S, Franziska K, et al. Influence of the Erodent Shape on the Erosion Behavior of Ductile and Brittle Materials. TribolLett, 2017, 65: 18.

[28] Camacho J, Lewis R, Dwyer-Joyce R S. Solid particle erosion caused by rice grains. Wear, 2009, 267: 223-232.

[29] Vite-Torres M, Laguna-Camacho J R, Baldenebro-Castillo R E, et al. Study of solid particle erosion on AISI 420 stainless steel using angular silicon carbide and steel round grit particles. Wear, 2013, 301: 383-389.

[30] Feng Z, Ball A. The erosion of four materials using seven erodents - towards an understanding. Wear, 1999, 233-235: 674-684.

[31] Akbarzadeh E, Elsaadawy E, Sherik A M, et al. The solid particle erosion of 12 metals using magnetite erodent. Wear 2012, 282-283: 40-51.

[32] Arabnejad H, Shirazi S A, McLaury B S, et al. The effect of erodent particle hardness on the erosion of stainless steel. Wear, 2015, 332-333: 1098-1103.

[33] Helzer S C, Vondra L F. A Systems Approach for the Selection of Tooling Materials in the Foundry, Cast Expo '93 and the 97th AFS Casting Congress. American FoundryMen's Society. Chicago Illinois, April 24-27, 1993.

[34] Formanek, Vondra L. A Further Evaluation of Wear Analysis of Selected Tooling Materials Using Impact Abrasions Testing. Cast Expo '96 and the 100th AFS Casting Congress. American Foundrymen's Society, April 20-23, 1996.

[35] Rodríguez J, Martínez D, Perez A, et al. Erosion Wear in Heat Treated Tool Steels Used in Core Boxes at Automotive Foundries. Wear, 2007, 263: 301-308.

[36] Rodriguez E, Flores M, Perez A, et al. Erosive Wear by Silica Sand on AISI H13 and 4140 Steels. Wear, 2009, 267: 21092115.

[37] Standard Practice for Conducting Erosion Tests by Solid Particle Impingement Using Gas Jets, G 76, Annual Book of ASTM Standards, Vol. 3.02, ASTM.

[38] Kim J J, Park S K. Solid particle erosion of AISI 403 stainless steel. Journal of Materials Science Letters, 1998, 17: 15031506.

[39] Rodríguez E. Desgaste Erosivo en Aleaciones para Cajas de Corazones, Ph.D. Thesis, Universidad Autónoma de Nuevo León, 2006, 121-160. (In Spanish) 